\title{
Cross-Sectional Study of Leptospira spp. and Brucela abortus in Goat Herds from Paraná State, Brazil
}

\author{
Aline Kuhn Sbruzzi Pasquali', Roberta Torres Chideroli ${ }^{2}$, Aline do Nascimento Benitez ${ }^{1}$, Eloiza Teles Caldart' \\ Fernanda Evers', Maira Salomão Fortes', Fernanda Pinto Ferreira', Keila Clarine Monteiro', \\ Lucienne Garcia Pretto Giordano², Roberta Lemos Freire', Júlio Cesar de Freitas ${ }^{2} \&$ Italmar Teodorico Navarro'
}

\begin{abstract}
Background: Leptospirosis and brucellosis are zoonosis worldwide distributed that have great economic importance, especially in goats. This study aimed to carry out a cross-sectional study to determine the prevalence of anti-Leptospira spp. and anti-Brucella abortus antibodies and to determine epidemiological variables associated to infection by these ethiological agents in goats.

Materials, Methods \& Results: Serum samples were collected from 1055 goats of 95 properties distributed in 18 regional centers of Paraná State from April to August of 2010. Collected samples were submitted to microscopic agglutination test (MAT) for the detection of anti-Leptospira spp. antibodies with 22 reference serovars: Australis, Bratislava, Autumnalis, Butembo, Castellonis, Bataviae, Canicola, Fortbragg, Whitcombi, Cynopteri, Grippotyphosa, Hebdomadis, Copenhageni, Icterohaemorrhagiae, Panama, Pomona, Pyrogenes, Hardjo, Wolffi, Shermani, Tarassovi and Londrina 1 (L1). The samples were also submitted to buffered acidified plate antigen test (BAPA) and 2-mercaptoethanol test (2-ME) to detect anti-Brucella abortus antibodies. The results obtained from epidemiological and serological study were analysed by Epi Info 3.5.3. We observed 9.9\% (104/1055) of goats reagents in at least one serovar of Leptospira spp. and no reagent animal to Brucella abortus. The variables that were statistically significant with leptospirosis were: production type meat, sewer destination in dry sump, frequent abortion, shared use of pastures, slaughter of animals on the property, the presence of pigs and wild animals such as deer and capybaras on the property.

Discussion: This was the first study about antibodies prevalence against Leptospira spp. and Brucella abortus in goat herds from Paraná State. The presence of both animal species were statiscally associated to risk of leptospirosis. It is necessary avoid the acess of these animals in herds, decreasing the dissemination of the agent. The production type meat is a form of creation in which the animals have no care of zookeepers and continuous veterinary care. The final destination of sewage was statistically associated to risk of leptospirosis in goats and this is a big problem in rural properties, requiring greater attention of authorities for proper disposal of this wastewater, reducing water and food contamination. Among the variables related to management, the herds that used rented pasture or shared pastures also were statistically associated to risk of leptospirosis in goats; with the sharing of pastures a greater flow of animals transiting in the pickets occurs, allowing not only flocks of goats, but other species also, to use the same pastures and become more exposed to certain diseases. The slaughter of pigs, sheep, cattle and goats on the property is a problem for animal and human health due to lack of sanitary inspection. Abortion is one of the main clinical signs of leptospirosis in farm animals, particularly goats. The knowledge of these results will be useful to develop control programs for the disease in Paraná State herds. The absence of circulating anti-Brucella abortus antibodies in goat herds has also been reported in other Brazilian States.
\end{abstract}

Keywords: property, serovars, leptospirosis, brucellosis, abortion. 


\section{INTRODUCTION}

Goat farming is an economic activity explored all around the world and which is expanding. In 2011, the Brazilian herd was estimated at 9,384,894 animals. The South Region has 341,637 animals [17], and of this total 185,206 animals are in Paraná State [18].

Leptospirosis is a zoonosis worldwide distributed caused by infection by any pathogenic member of the genus Leptospira [8,9,34], almost present in all countries, its occurrence is associated with moist periods [23,25]. The reservoirs of leptospirosis are synanthropic and domestic animals, rodents are one of the main disseminators of the agent by the urine [4]. This disease can cause abortions and high mortality rate (over 40\%) in young goats [3]. The serovars most commonly found in goats are Grippotyphosa, Pomona, Icterohaemorrhagiae, Autumnalis, Sejroe, Ballum and Canicola [25].

Brucella melitensis is considered the main species of Brucella that affects goats. However, due to the co-creation of goats and cattle, there is the possibility to detect Brucella abortus in this species. The disease is characterized by reproductive signs such as abortions in the final stage of pregnancy, premature birth, infertility and low milk production [19].

The aim of this work was to carry out an epidemiological cross-sectional study in goat herds from Paraná State, with the determination of the prevalence of antibodies anti-Leptospira spp. and anti-Brucella abortus and to determine variables related to environmental characteristics and property management associated to infection by these ethiological agents.

\section{MATERIALS AND METHODS}

\section{Epidemiological Analysis}

The state of Paraná is located in the southern region of Brazil with an extension of $199,709 \mathrm{Km}^{2}$. It consists of 20 regional units of animal health, $399 \mathrm{mu}-$ nicipalities and 4,515 properties of goat farming [26]. We have conducted a cross-sectional observational study. To raffle the goat herds and the animals to be selected to the study a database of 4,515 properties and 80,780 animals from SEAB-2009 was used. To calculate the sample size EpiInfo 3.5. ${ }^{1}$ [7] was used with a prevalence estimated at $50 \%$, error of $3.5 \%$, $95 \%$ of confidence level and Deff of 1.5 , resulting in 1,055 young and adult animals for a cluster sampling.
The sampling was performed in two stages: in the first stage, 95 properties were systematically raffled, covering 18 of the 20 regional units of animal health from Paraná State, in the second stage, goats were randomly selected according to the total number of animals on each property.

The samples were collected from April to August of 2010 after the signatures of a knowledge and authorization document by the owners. Blood collection was done by jugular venipuncture with $40 \mathrm{~mm}$ x $12 \mathrm{~mm}$ needles in vacuum tubes without anticoagulant. For the analysis of variables associated with Leptospira spp. and Brucella abortus infection, the owners answered an epidemiological questionnaire with information about the property, creation system, environmental and herd variables, such as: cleaning installations frequency, source of drinking water, final destination of sewage, the presence of marshy areas, sex, age, breeding system, production type, breed, management, presence of veterinary assistance, pastures in common with other properties, slaughtering of animals on the property, the presence of other livestock and/or wild animals, acquisition of new animals, requirement tests for the acquisition of new animals, annual worming, abortion, heat repetition and reproductive problems.

\section{Serological Tests}

All serum samples were tested for the detection of anti-Leptospira spp. antibodies with 22 reference serovars: Australis, Bratislava, Autumnalis, Butembo, Castellonis, Bataviae, Canicola, Fortbragg, Whitcombi, Cynopteri, Grippotyphosa, Hebdomadis, Copenhageni, Icterohaemorrhagiae, Panama, Pomona, Pyrogenes, Hardjo, Wolffi, Shermani, Tarassovi and Londrina 1 (L1).

Antigen cultures were maintained at $28^{\circ} \mathrm{C}$ from 5 to 10 days in modified EMJH medium (DIFCO®1). Serum samples able to agglutinate at least $50.0 \%$ of leptospires starting from titer levels of 100 were considered positive for leptospirosis. The sera from positive animals were diluted twofold to determine the maximum positive dilution [10].

Serovars with the higher agglutination titers were considered the most likely match for animals. Samples with co-agglutination at the highest dilutions were considered reactive only to Leptospira interrogans.

On the property, the most likely match serovar showed the largest titer and the highest number of 
positive reactions. A property was considered positive when presented at least one reagent animal to Leptospira interrogans.

All samples were tested to Brucella abortus antigen by buffered acidified plate antigen test (BAPA2) and 2-mercaptoethanol test (2-ME2). The antigen for BAPA consisted of an inactivated cell suspension of Brucella abortus strain 1119-3, pH $3.65 \pm 0.05$, in a concentration of $8 \%$. For 2-ME test the concentration was $4.5 \%$ (Paraná Institute of Technology - Tecpar). The BAPA was considered positive when macroscopic agglutination occurred and 2-ME was considered positive when there was formation of a precipitated film on the bottom of the tube and clear supernatant. The sample was considered positive when reagent in both serological tests.

Statistical Analysis

The results obtained from epidemiological and serological study were analysed by Epi Info 3.5.3 [7]. Statistical significance of observed results and the expected ones, were analysed by Chi square $\left(\chi^{2}\right)$ and Fisher's exact tests in a $5.0 \%$ of significance level. The measure of association was determined by Odds ratio (OR) in a confidence interval (CI) of $95 \%$.

\section{RESULTS}

From 1,055 goat sera analyzed, $9.9 \%$ (104/1055; $95 \%$ CI 8.12 to $11.81 \%$ ) were positive for Leptospira spp., while for Brucella abortus were negative. The reactive sera (104) had antibodies with the following titles: $100(72.1 \% ; 75 / 104), 200$ (14.4\%; 15/104), $400(10.6 \%$; 11/104), 800 (1, 9\%, $2 / 104)$ and $1,600(1.0 \% ; 1 / 104)$. The most prevalent serovars in animals were Pyrogenes $21.15 \%$ (22/104), Hardjo $18.27 \%$ (19/104) and Bratislava $10.58 \%(11 / 104)$. Among the 95 properties analyzed $48.42 \%(46 / 95)$ had at least one reagent animal. The most prevalent serovars in the properties were Pyrogenes $21.74 \%$ (10/46), Hardjo $10.87 \%$ (5/46) and Autumnalis $10.87 \%$ (5/46). The other serovars in reagent animals and positive properties are described in Table 1.

The variables in the epidemiological study analyzed by statistical significance are described in Table 2.

Table 1. Most prevalent serovars for Leptospira spp. in reagent goats and positive properties in Paraná State, 2010.

\begin{tabular}{ccccc}
\hline Serovar & $\begin{array}{c}\text { Reagent } \\
\text { Animals }\end{array}$ & $(\%)$ & $\begin{array}{c}\text { Positive } \\
\text { Properties }\end{array}$ & $(\%)$ \\
\hline Pyrogenes & $22 / 104$ & 21.15 & $10 / 46$ & 21.74 \\
Hardjo & $19 / 104$ & 18.27 & $5 / 46$ & 10.87 \\
Bratislava & $11 / 104$ & 10.58 & $4 / 46$ & 8.70 \\
Autumnalis & $9 / 104$ & 8.65 & $5 / 46$ & 10.87 \\
Fortbragg & $8 / 104$ & 7.70 & $2 / 46$ & 4.35 \\
Icterohaemorrhagiae & $6 / 104$ & 5.77 & $3 / 46$ & 6.52 \\
Canicola & $5 / 104$ & 4.81 & $4 / 46$ & 8.70 \\
Butembo & $4 / 104$ & 3.85 & $2 / 46$ & 4.35 \\
Copenhageni & $2 / 104$ & 1.92 & $2 / 46$ & 4.35 \\
Grippotyphosa & $2 / 104$ & 1.92 & - & - \\
Shermani & $2 / 104$ & 1.92 & - & - \\
Australis & $1 / 104$ & 0.96 & - & - \\
Pomona & $1 / 104$ & 0.96 & $1 / 46$ & 2.17 \\
Tarassovi & $1 / 104$ & 0.96 & $1 / 46$ & 2.17 \\
Serologic draw* & $11 / 104$ & 10.58 & & \\
Not determined serovar** & - & - & $1 / 46$ & 2.17 \\
Several prevalent serovars*** & - & - & $6 / 46$ & 10.04 \\
\hline
\end{tabular}


A.K.S. Pasquali, R.T. Chideroli, A.N. Benitez, et al. 2017. Cross-Sectional Study of Leptospira spp. and Brucela abortus in Goat Herds from Paraná State, Brazil.

Table 2. Characteristics of the property, management and reproductive problems statistically associated to reagent goats to Leptospira spp. in Paraná State, 2010.

\begin{tabular}{|c|c|c|c|c|}
\hline Variable & Reagents/Total & $(\%)$ & $\mathrm{P}$ - value & OR (CI 95\%) \\
\hline \multicolumn{5}{|l|}{ Production type } \\
\hline Meat & $96 / 851$ & 11.3 & 0.0063 & \\
\hline Milk & $1 / 16$ & 6.3 & & \\
\hline Mixed & $7 / 188$ & 3.7 & & \\
\hline \multicolumn{5}{|c|}{ Sewer destination } \\
\hline Dry sump & $83 / 710$ & 11.7 & 0.0139 & \\
\hline Septic sump & $17 / 256$ & 6.6 & & \\
\hline Others & $4 / 89$ & 4.5 & & \\
\hline \multicolumn{5}{|c|}{ Sharing pastures } \\
\hline Yes & $11 / 42$ & 26.2 & 0.0015 & $3.51(1.70-7.21)$ \\
\hline No & 93/1013 & 9.2 & & \\
\hline \multicolumn{5}{|c|}{ Sheep slaughtered on the property } \\
\hline Yes & $66 / 552$ & 12.0 & 0.0218 & $1.66(1.09-1.09)$ \\
\hline No & $38 / 503$ & 7.6 & & \\
\hline \multicolumn{5}{|c|}{ Pig slaughtered on the property } \\
\hline Yes & $79 / 678$ & 11.7 & 0.0119 & $1.85(1.16-2.96)$ \\
\hline No & $25 / 377$ & 6.6 & & \\
\hline \multicolumn{5}{|c|}{ Cattle slaughtered on the property } \\
\hline Yes & $53 / 433$ & 12.2 & 0.0393 & $1.56(1.04-2.34)$ \\
\hline No & $51 / 622$ & 8.2 & & \\
\hline \multicolumn{5}{|c|}{ Goats slaughtered on the property } \\
\hline Yes & $94 / 861$ & 10.9 & 0.0214 & $2.25(1.15-4.41)$ \\
\hline No & $10 / 194$ & 5.2 & & \\
\hline \multicolumn{5}{|l|}{ Presence of pigs } \\
\hline Yes & $90 / 747$ & 12.0 & 0.0003 & $2.87(1.61-5.13)$ \\
\hline No & $14 / 308$ & 4.5 & & \\
\hline \multicolumn{5}{|c|}{ Presence of wild animals } \\
\hline Yes & $81 / 696$ & 11.6 & 0.0095 & $1.92(1.18-3.11)$ \\
\hline No & $23 / 359$ & 6.4 & & \\
\hline \multicolumn{5}{|c|}{ Presence of capybaras } \\
\hline Yes & $45 / 350$ & 12.9 & 0.0283 & $1.61(1.07-2.43)$ \\
\hline No & $59 / 705$ & 8.4 & & \\
\hline \multicolumn{5}{|c|}{ Presence of deer } \\
\hline Yes & $41 / 244$ & 16.8 & 0.00005 & $2.39(1.57-3.65)$ \\
\hline No & $63 / 811$ & 7.8 & & \\
\hline \multicolumn{5}{|c|}{ Frequent abortion } \\
\hline Yes & $36 / 258$ & 14.0 & 0.0133 & $1.76(1.14-2.71)$ \\
\hline No & $67 / 795$ & 8.4 & & \\
\hline
\end{tabular}


The results indicate that $75.5 \%(797 / 1055)$ were female, $72.1 \%(575 / 797)$ were more than one year old. Males were $24.4 \%(257 / 1055)$ and $46.6 \%$ $(125 / 257)$ were more than one year old. The predominant farming system was the extensive, with $51.7 \%(545 / 1055)$; followed by the semi-extensive, with $41.0 \%$ (433/1055) and the confined, with $7.3 \%$ (77/1055). The meat production was predominant with $80.7 \%$ (851/1055) followed by mixed production $17.8 \%(188 / 1055)$ and $1.5 \%$ was milk production (16/1055). In relation to the breed, 60.2\% (635/1055) of the goats were crossbreed; $29.6 \%(342 / 1055)$ were Boer and 4.6\% (49/1055) were Saanen.

In relation to the properties installations, $31.6 \%$ (30/95) performed cleaning three times in a year; $9.5 \%$ (9/95) two times in a year; $21.1 \%$ (20/95) one time in a year and 36.8\% (35/95) did not perform cleaning. The origin of drinking water was mines and streams for $91.6 \%$ (87/95) of animals and 86.3\% (82/95) of human. The sewage destination was dry sump in $62.1 \%$ $(59 / 95)$ of the properties wetlands were present in $31.6 \%(30 / 95)$ of them.

The results regarding to the presence of other animal species indicate that $97.9 \%(93 / 95)$ of the properties had dogs, $73.7 \%$ (70/95) cats, $85.3 \%$ (81/95) cattle, in $61.1 \%(58 / 95)$ of the properties goats and cattle lived together; $70.5 \%$ (67/95) of the properties had the presence of wild animals: $26.3 \%(25 / 95)$ of capybaras, $16.8 \%$ (16/95) of cervids and 83.2\% (79/95) of rodents. In relation to the management of properties, $37.9 \%$ (36/95) had veterinary care, $92.6 \%$ (87/95) did not share pastures with other properties, $73.7 \%$ (70/95) of goats were slaughtered or intented for consumption and $66.3 \%$ (63/95) of the animals were slaughtered on the property.

Regarding the health of livestock, during two years prior to the study there was the acquisition of animals in $46.3 \%$ (44/95) of the properties, $87.4 \%$ (83/95) had done worming annually, $18.9 \%$ (18/95) of the properties had reproductive problems, including: abortion in $21.1 \%$ (20/95) or heat repetition in $11.6 \%$ (11/95).

\section{DISCUSSION}

In small ruminants, particularly goats, few studies have been conducted in Brazil in order to identify risk factors associated with infection by Leptospira spp. [16]. Paraná State does not have epidemiological studies in this way, which highlights the importance of performing this work, considering that leptospirosis has great economic importance and causes direct and indirect damage to herds, among them goats.

During years 2003 and 2004, in a study in Rio de Janeiro State were observed a prevalence of $11.1 \%$ (111/1000) [19] and in the semi-arid of Paraíba State found $8.7 \%$ (98/975) of reagents goats [14], both results were close to those found in this work. While in Rio Grande do Sul State a prevalence of 3.4\% (12/354) in dairy goats were found [31], this can be justified by the fact that dairy farms have higher veterinary care and better care in managements, reducing the risk of infection.

In Uberlândia city Minas Gerais State, found a prevalence of anti-Leptospira spp. antibodies in $31.30 \%(72 / 230)$ of goats, and $66.67 \%$ of the titers were 100 [30], this results are similar to ours $(72.1 \%$; $75 / 104$ with title 100), demonstrating the chronicity of reactive animals in epidemiological studies. The chronicity found shows the risk of further spread of the agent to other animals and humans, as these goats with low levels of antibodies, can be carriers and eliminate the bacteria to the environment, without any clinical signs.

When we analyze the dispersion of agents between the regions we can observe variations in prevalence in flocks. Schmidt, Arosi \& Santos [31] studied the prevalence of leptospirosis in 22 properties of dairy goats in Rio Grande do Sul State and found a prevalence of $13.64 \%(3 / 22)$. In the semi-arid region of the Northeast, Higino et al. [15] found 43.6\% (48/110) of the properties with positive animals, showing a prevalence in herds similar to our study $48.42 \%$ (46/95).

This was the first study of the prevalence of anti-Leptospira spp. antibodies in goats in Paraná State, in which a homogeneous distribution of properties with reagent animals throughout the state was observed, as can be seen in Figure 1.

Among reagent goats, the most likely prevalent serovars observed were: Pyrogenes $21.15 \%$ (22/104), Hardjo $18.27 \%(19 / 104)$ and Bratislava $10.58 \%$ $(11 / 104)$, while in the positive properties the most likely prevalent serovars were: Pyrogenes $21.74 \%$ (10/46), Hardjo 10.87\% (5/46) and Autumnalis 10.87\% (5/46). In São Paulo, was reported a prevalence of $2.4 \%$ $(15 / 616)$ in goats, the most likely prevalent serovar was Pyrogenes with $21 \%$ of the reagent animals [11], similar to the results found in this study $(21.15 \%)$. 
However in Minas Gerais State had lower results for the prevalence of this serovar $(13.13 \%)$, this can be justified by the ecosystem and the presence of wild animals [30]. Pyrogenes serovar was isolated in wild animals, humans, Uganda cattle, goats and sheep from Sudan [12]. In Brazil was isolated from wild animals [29]. In this work the variable presence of wild animals $(P=0.0095)$ (deer with $P=0.00005$ and capybaras with $P=0.0283$ ) was statistically associated to risk of leptospirosis in goats. It is known that wild animals are reservoirs of serovar Pyrogenes and can be the source of infection and spread of the agent to herds. In a study in cattle herds of Maranhão also noted that the presence of wild animals like capybaras and deer were risk variables for leptospirosis [32]. Due to the increasing ecological imbalance, wild animals, especially capybaras, tend to migrate to urban centers and crops, causing further spread of the agent [6].

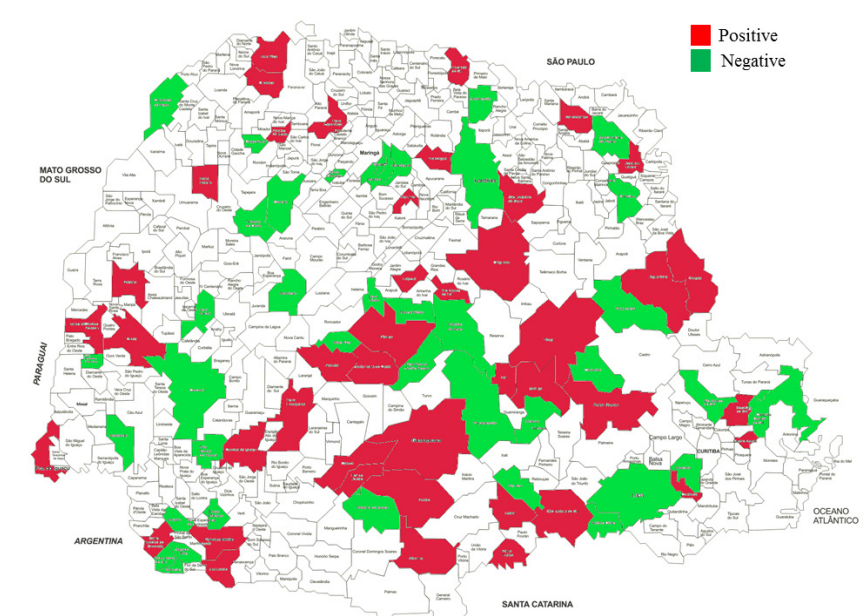

Figure 1. Geographical map with distribution of municipalities with at least one property with at least one animal reagent to Leptospira spp., Paraná, 2010.Source: Map adapted available in: http://www. zonu.combrazil_mapsParana_State_Municipality_Map_Brazil.htm. [Accessed in 18 January 2014].

In a study in Rio de Janeiro State, observed $42.7 \%$ of goats reagents to Hardjo serovar, results superior to that found in our study $(18.27 \% ; 19 / 104)$. Regarding the properties, in this study the serovar Hardjo was the second most likely prevalent (10.87\%; 5/46) [22]. Superior results were found in Rio de Janeiro State, where they observed $72.1 \%$ of the positive properties for that serovoar [19]. The serovar Hardjo can be present in bovines, sheep and pigs as reservoir, and in this study the presence of pigs in properties was statistically $(P=0.0003)$ associated to risk of leptospirosis in goats. Similar results were observed in cattle study in Bahia State, where pig farming was also associated factor with leptospirosis, which is an important reservoir for serovars as Hardjo, Pomona, among others [24]. Bratislava was the third most prevalent serovar with $10.58 \%$ (11/104) of the reagent goats, being that this serovar presents as main reservoirs: pigs, horses and rodents. In a study in Rio de Janeiro State, observed lower prevalence than found in our study, with only $3.8 \%$ of reacting animals [20]. It indicates that Hardjo and Bratislava serovars are keeping in herds through the dissemination of pigs to goats and vice versa, since the presence of pigs in properties was statistically associated to leptospirosis in the present goat population.

In semi-arid of Paraíba State found the Autumnalis serovar as the most prevalent in properties with positive animals, being observed in $10.9 \%(12 / 110)$ of them [14]. These results were similar to that observed in our study that had the Autumnalis serovar as the third most probable with $10.87 \%(5 / 46)$ of the positive properties. This serovar has as main reservoir the rodents, animals that were present in $83.2 \%$ of the properties according to the epidemiological questionnaire (not statistically significant). This reservoir was present in flocks enabling the delivery of Leptospira spp. to other animals and humans, showing great health and public health concern.

In the analyzed properties the production type (meat, milk and mixed) were statistically ( $P=$ 0.0063 ) associated to risk of leptospirosis in goats, and most properties had production type meat $(80.7 \%$; $851 / 1055)$. In a study with cattle in Mato Grosso do Sul State, observed that the production type meat had 12.17 times more chances to have infection for at 
least one serovar of Leptospira spp. when compared to production type milk or mixed [13]. The production type meat is a form of creation in which the animals have no care of zookeepers and continuous veterinary care, in this type of farm animals are in the field, grazing away from the center of individual managements, taking care sporadically, more predisposed to the risk of spreading disease among them.

Among the environmental variables, the final destination of sewage was statistically $(P=0.01390)$ associated to risk of leptospirosis in goats, and the answer dry sump was more present with $11.7 \%$ (83/710). This is a big problem in rural properties, requiring greater attention of authorities for proper disposal of this wastewater, reducing water and food contaminationin. In a study of canine leptospirosis in Curitiba Paraná State, found that areas with lower socioeconomic and environmental conditions, with the presence of open sewers near homes, garbage and debris had statistically higher risk for spread of leptospirosis [2].

Among the variables related to management, the herds that used rented pasture or shared pastures also were statistically $(P=0.0015)$ associated to risk of leptospirosis in goats. Similar results were found in a study with cattle in Bahia State [24], where the share of pasture was presented as an associated factor, which suggests the contamination of pastures and water by the animals coming from other properties and by the intense movement of new animals. With the sharing of pastures a greater flow of animals transiting in the pickets occurs, allowing not only flocks of goats, but other species also, to use the same pastures and become more exposed to certain diseases.

The slaughter of pigs, sheep, cattle and goats on the property showed statistical $(P=0.0214)$ association to risk of leptospirosis in goats. Which is a problem for animal and human health, for not having sanitary inspection nor sanitary conditions suitable for personal protection to the operator and to the consumer of the final product. The same was observed by in a study of cattle properties in Bahia State, where they noted that the slaughter of animals on the farm was a variable associated with the risk of leptospirosis [24].
The variable frequent abortion appeared as statistically ( $P=0.0133$ ) associated, and abortion is one of the main clinical signs of leptospirosis in farm animals, particularly goats. A study with goat herds in Espírito Santo State found a higher risk of occurrence of abortion, with 15.61 times greater chance of miscarriages in animals reagents in serology for leptospirosis compared to not reagents [5]. Prevalence of $48.8 \%$ $(61 / 125)$ in females reagents for Leptospira spp. in an outbreak, in which the main clinical sign observed was abortion [21].

The absence of circulating anti-Brucella abortus antibodies in the studied herds has also been reported in northeastern Brazil [1], with prevalence between $0.6 \%$ [27] and $0.2 \%$ [33].

\section{CONCLUSIONS}

In this study, it was observed that the most prevalent serovars circulating in animals and properties were Pyrogenes and Hardjo. The main reservoirs of these serovars are wild animals and pigs, respectively. The presence of both animal species were statiscally associated to risk of leptospirosis. It is necessary avoid the acess of these animals in herds, decreasing the dissemination of the agent.

The factors statistically associated with leptospirosis, that remain not described in goat herds, are: production type meat, sewer destination in dry sump, shared use of pastures, slaughter of animals on the property, the presence of pigs and wild animals such as deer and capybaras on the property. The knowledge of these results will be useful to develop control programs for the disease in Paraná State herds, since this epidemiological study is the first in the state.

\section{MANUFACTURERS}

${ }^{1}$ BD Biosciences. Franklin Lakes, NJ, USA.

${ }^{2}$ TECPAR Instituto de Biocências do Paraná. Curitiba, PR, Brazil.

Ethical approval. The project was approved by the Ethics Committee on Animal Use of the Institution in which the study was conducted (CEUA No 73/2009).

Declaration of interest. The authors report no conflicts of interest. The authors alone are responsible for the content and writing of the paper.

\section{REFERENCES}

1 Alves C.J., Vasconcelos S.A., Morais Z.M., Leite E.A. \& Gomes A.A.B. 1997. Avaliação dos níveis de aglutininas anti-Brucella em soros de caprinos de cinco centros de criação do nordeste do Brasil. Revista Brasileira de Ciência Veterinária. 4(3): 89-91. 
A.K.S. Pasquali, R.T. Chideroli, A.N. Benitez, et al. 2017. Cross-Sectional Study of Leptospira spp. and Brucela abortus in Goat

2 Bier D., Simakura S.E., Morikawa V.M., Ullmann L.S., Kikuti M., Langoni H., Biondo A.W. \& Molento M.B. 2013. Análise espacial do risco de leptospirose canina na Vila Pantanal, Curitiba, Paraná. Pesquisa Veterinária Brasileira. 33(1): 74-79.

3 Brasil. Ministério da Agricultura. 2004. Instrução Normativa No 87 de 10 de dezembro de 2004. Regulamento Técnico do Programa Nacional de Sanidade dos Caprinos e Ovinos. Diário Oficial da União, sec. 01, pag. 21, 20 dez. 2004.

4 Brasil. Ministério da Saúde. Secretaria de Vigilância em Saúde. 2009. Guia Leptospirose: Diagnóstico e Manejo Clínico, Secretaria de Vigilância em Saúde. 34p.

5 Costa P.C. 2013. Soroprevalência para Leptospira spp. em rebanhos caprinos e ovinos no estado do Espírito Santo, relacionado com o sistema de manejo e sinais reprodutivos. 102p. Vitória, ES. Dissertação (Mestrado em Ciências Veterinárias) - Programa de Pós-graduação em Ciências Veterinárias, Universidade Federal do Espírito Santo.

6 Cueto G.R., Allekotte R. \& Kravetz F.O. 2000. Scurvy in capybaras bred in captivity in Argentine. Jounal Wildife Diseases. 36(1): 97-101.

7 Dean A.G., Dean J.A., Burton A.H. \& Dicker R.C. 1990. Epi Info: a general-purpose microcomputer program for public health information systems. American Journal of Preventive Medicine. 7(3): 178-182.

8 Faine S. 1982. Guidelines for the control of leptospires. 2nd edn. Geneva: World Health Organization, 171p.

9 Faine S. 1994. Leptospira and leptospirosis. Boca Raton: CRC Press, 368p.

10 Faine S., Adler B., Bolin C.A. \& Perolat P. 1999. Leptospira and leptospirosis. 2nd edn. Melbourne: Medisci, 272p.

11 Favero A.C.M., Pinheiro S.R., Vasconcellos S.A., Morais Z.M., Ferreira F., Ferreira S. \& Neto J. 2002. Sorovares de Leptospiras predominantes em exames sorológicos de bubalinos, ovinos, caprinos, equinos, suínos e cães de diversos estados brasileiros. Ciência Rural. 32(4): 613-619.

12 Feresu S.B., Bolin C.A., Korver H. \& Terpstra W.J. 1994. Classification of Leptospires of the Pyrogenes Serogroup Isolated from Cattle in Zimbabwe by Cross-Agglutinin Absorption and Restriction Fragment Length Polymorphism Analysis. International Journal of Systematic Bacteriology. 44(3): 541-546.

13 Figueiredo A.O., Pellegrini A.O., Gonçalvez V.S.P., Freitas E.B., Monteiro L.A.R.C., de Oliveira J.M. \& Osório A.L.A.R. 2009. Prevalência e fatores de risco para a leptospirose em bovinos de Mato Grosso do Sul. Brazilian Veterinary Research. 29(5): 375-381.

14 Higino S.S.S., Alves C.J. Santos C.S.A.B., Vasconcelos S.A., Silva M.L.C.R., Brasil A.W.L., Pimenta C.L.R.M. \& Azevedo S.S. 2012. Prevalência de leptospirose em caprinos leiteiros do semiárido paraibano. Brazilian Veterinary Research. 32(3): 199-203.

15 Higino S.S.S., Santos F.A., Costa D.F., Santos C.S.A.B., Silva M.L.C.R., Alves C.J. \& Azevedo S.S. 2013. Flocklevel risk factors associated with leptospirosis in dairy goats in a semiarid region of Northeastern Brazil. Preventive Veterinary Medicine. 109(1): 158-161.

16 Higino S.S.S. \& Azevedo S.S. 2014. Leptospirose em pequenos ruminantes: situação epidemiológica atual no Brasil. Arquivos do Instituto Biológico. 81(1): 86-94.

17 Instituto Brasileiro de Geografia e Estatística (IBGE). 2011. Pesquisa da Pecuária Municipal. Avaliable in: <ftp:// ftp.ibge.gov.br/Producao_Pecuaria/Producao_da_Pecuaria_Municipal/2011/tabelas_pdf/tab01.pdf >. [Acessed in 12/2013].

18 Instituto Paranaense de Desenvolvimento Econômico e Social (IPARDES) 2012. Caderno estatístico estado do Paraná. Avaliable in: <http://www.ipardes.gov.br/cadernos/Montapdf.php?Municipio=00019>. [Acessed in 12/2013].

19 Lilenbaum W., Souza G.N., Ristow P., Moreira M.C., Fráguas S., Cardoso V.S. \& Oelemann W.M.R. 2007. A serological study on Brucella abortus, caprine arthritis-encephalitis virus and Leptospira in dairy goats in Rio de Janeiro, Brazil. The Veterinary Journal. 173(2): 408-412.

20 Lilenbaum W., Varges R., Medeiros L., Cordeiro A.G., Cavalcanti A., Souza G.N., Richtzenhain L. \& Vasconcellos S.A. 2008. Risk factors associated with leptospirosis in dairy goats under tropical conditions in Brazil. Research in Veterinary Science. 84(1): 14-17.

21 Martins G., Brandão F.Z., Hamond C., Medeiros M. \& Lilenbaum W. 2012. Diagnosis and control of an outbreak of Leptospirosis in goats with reproductive failure. The Veterinary Journal. 193(2): 600-601.

22 Martins G., Penna B., Hamond C., Leite R.C.-K., Silva A., Ferreira A., Brandão F., Oliveira F. \& Lilenbaum W. 2012. Leptospirosis as the most frequent infectious disease impairing productivity in small ruminants in Rio de Janeiro, Brazil. Tropical Animal Health Production. 44(4): 773-777. 
23 Morikawa V.M. 2010. Estudo sorológico da infecção por Leptospira spp. em uma área de ocupação irregular e de alto risco para a doença em cães em Curitiba, PR. 72p. Curitiba, PR. Dissertation (Mestrado em Ciências Veterinárias) Programa de Pós-Graduação em Ciências Veterinárias, Universidade Federal do Paraná.

24 Oliveira F.C.S., Azevedo S.S., Pinheiro S.R., Batista C.S.A., Moraes Z.M., Souza G.O., Gonçalves A.P. \& Vasconcellos S.A. 2010. Fatores de risco para a leptospirose em fêmeas bovinas em idade reprodutiva no Estado da Bahia, Nordeste do Brasil. Brazilian Veterinary Research. 30(5): 398-402.

25 Oliveira S.V., Arsky M.L.N.S. \& Caldas E.P. 2013. Reservatórios animais da leptospirose: Uma revisão bibliográfica. Revista Saúde. 39(1): 9-20.

26 Paraná. Departamento de Economia Rural. Secretaria da Agricultura e Abastecimento. 2009. Avaliable in: <http:// www.agricultura.pr.gov.br/modules/conteudo/conteudo.php? conteudo=74>. [Acessed in 12/2013].

27 Pinheiro Jr. J.W., Souza M.M.A., Guerra N.R., Santana V.L.A. \& Mota R.A. 2008. Freqüência de aglutininas antiBrucella abortus em caprinos e ovinos do sertão do estado de Pernambuco, Brasil. Ciência Animal Brasileira. 9(4): 1096-1101.

28 Salles R.S. \& Lilenbaum W. 2006. Leptospirose bovina no Brasil. Revista CFMV. 21(1): 42-46.

29 Santa Rosa C.A., Sulzer C.R., Yanaguita R.M. \& Silva A.S. 1980. Leptospirosis in wildlife in Brazil: Isolation of serovars Canicola, Pyrogenes and Grippotyphosa. Internatinal Journal Zoonosis. 7(1): 40-43.

30 Santos J.P., Lima-Ribeiro A.M.C., Oliveira P.R., Santos M.P., Ferreira Jr A., Medeiros A.A. \& Tavares T.C.F. 2012. Seroprevalence and risk factors for Leptospirosis in goats in Uberlândia, Minas Gerais, Brazil. Tropical Animal Health Production. 44(1):101-106.

31 Schmidt V., Arosi A. \& Santos A.R. 2002. Levantamento sorológico da Leptospirose em caprinos leiteiros no Rio Grande do Sul, Brasil. Ciência Rural. 32(4): 609-612.

32 Silva F.J., Conceição W.L.F., Fagliari J.J., Girio R.J.S., Dias R.A., Borba M.R. \& Mathias L.A. 2012. Prevalência e fatores de risco de leptospirose bovina no Estado do Maranhão. Brazilian Veterinary Research. 32(4): 303-312.

33 Simon S.A.F., Ristow P., Cardoso V.S., Souza G.N. \& Lilenbaum W. 2004. Ocorrência de brucelose caprina em propriedades de exploração leiteira do estado do Rio de Janeiro. Brazilian Journal of Veterinary Medicine. 26(1): 2125.

34 World Health Organization for Animal Health (WHO). 2008. Leptospirosis. Avaliable in: <http://www.oie.int/ fileadmin/Home/eng/Health_standards/tahm/2.01.09__LEPTO.pdf>. [Acessed in 12/2013]. 